\title{
RANCANG BANGUN SISTEM PENDUKUNG KEPUTUSAN PEMILIHAN HANDPHONE BERBASIS WEB DENGAN METODE FMADM
}

\author{
Kadek Cahyadi \\ Program Studi Sistem Komputer, STMIK STIKOM, Bali \\ lolospyboyz@gmail.com
}

\begin{abstract}
Decision Support System is an interactive system that supports the decision in the decision making process through the alternatives obtained from the data processing, information and design models. Mobile phone no longer a luxury item, presence now a days is a must have item for every person. In the end a lot of confusion when people want to select the desired phone, whetherit is in accordance with the requirements desired for a cell phone number so many and has it's own charm. In making the selection decision support system phones with FMADM method, research method used is the collection of data through observation, interview and literature study. The design of the system include flow charts, data flow diagrams, entity relationship diagram (ERD) and the conceptual database. Then implement it using a programming language used to build applications of decision support systems is the programming language PHP with MySQL database. With the web-based decision support system will be the technology that not only provides convenience, but able to provide solutions to an individual in choosing the right mobile phone and also in accordance with the requirements.
\end{abstract}

Keywords : System, Decision Support, FMADM

\begin{abstract}
ABSTRAK
Sistem Pendukung Keputusan merupakan suatu sistem interaktif yang mendukung keputusan dalam proses pengambilan keputusan melalui alternatif - alternatif yang diperoleh dari hasil pengolahan data, informasi dan rancangan model. Handphone bukan lagi menjadi barang yang mewah, kehadirannya saat ini sudah menjadi barang yang wajib dimiliki oleh setiap orang. Akhirnya banyak orang kebingungan ketika hendak memilih handphone yang diinginkan, apakah sudah sesuai dengan kebutuhan yang diinginkan karena jumlah handphone yang begitu banyak dan memiliki daya tarik tersendiri. Pada pembuatan sistem pendukung keputusan pemilihan handphone dengan metode FMADM, metode penelitian yang digunakan adalah pengumpulan data melalui observasi, wawancara serta studi literatur. Perancangan sistemnya meliputi flow chart, data flow diagram, entity relationship diagram (ERD) dan konseptual database. Kemudian mengimplementasikannya menggunakan Bahasa pemrograman yang digunakan untuk membangun aplikasi sistem pendukung keputusan ini adalah bahasa pemrograman PHP dengan database MySQL. Dengan adanya sistem pendukung keputusan berbasis web ini akan menjadi teknologi yang tidak hanya memberikan kemudahan, namun mampu memberikan solusi kepada seseorang dalam memilih handphone yang tepat dan juga sesuai dengan kebutuhan yang diinginkan.
\end{abstract}

Kata kunci : Sistem, Pendukung Keputusan, FMADM 


\section{PENDAHULUAN}

Kemajuan teknologi tidak hanya berkisar pada perkembangan teknologi komputer, teknologi komunikasi juga mengalami perkembangan pesat. Sejak ditemukannya telepon oleh Graham Bell sekitar tahun 1876, teknologi komunikasi telah berkembang menjadi televisi, email, sms dan video call. Salah satu perangkat komunikasi yang ada adalah handphone.

Handphone saat ini sudah bukan lagi menjadi barang yang mewah, kehadirannya saat ini sudah menjadi barang yang wajib dimiliki oleh setiap orang, baik itu pegawai negeri, swasta, buruh pabrik, petani, nelayan, tukang kayu, tukang batu, bahkan sampai anak-anak SD. Dampaknya muncul berbagai merk handphone, mulai dari handphone Nokia, Sony Ericsson, Samsung, LG dan lain sebagainya yang menyajikan berbagai fitur dan fasilitas. Saat ini handphone juga dilengkapi dengan fasilitas sms, gprs, mms, kamera, internet, game, kalkulator, radio, walkman dan masih banyak lagi. Akhirnya banyak orang kebingungan ketika hendak memilih handphone, apakah sudah sesuai dengan kebutuhan yang diperlukan buat mereka karena jumlah handphone yang begitu banyak dan memiliki daya tarik tersendiri.

Karena itu, kita membutuhkan suatu analisis untuk pendukung pengambilan keputusan dalam pemilihan handphone berbasis web yang dapat menghasilkan keputusan dari berbagai alternatif yang ada dalam memilih handphone. Dimana dalam rancang bangun sistem pendukung keputusan pemilihan handphone berbasis web ini akan digunakan suatu metode yaitu dengan menggunakan metode Fuzzy MADM. Fuzzy Multiple Attribute Decision Making adalah suatu metode yang digunakan untuk mencari alternatif optimal dari sejumlah alternatif dengan kriteria tertentu. Rancang bangun sistem pendukung pemilihan handphone berbasis web ini diharapkan mampu memberikan kemudahan dan membantu peminat handphone dalam pengambilan keputusan untuk memberikan bayangan atau referensi sesuai dengan yang diinginkan oleh user.

Dari kondisi di atas maka penulis melakukan penelitian untuk membuat suatu sistem dengan judul "Rancang Bangun Sistem Pendukung Keputusan Pemilihan Handphone Berbasis Web dengan Metode FMADM".

\section{TINJAUAN PUSTAKA \\ Pengertian Keputusan}

Adapun pengertian dari keputusan

yaitu dapat dijabarkan sebagai berikut (Hasan, 2002:9).

Menurut Ralp C. Davis

Keputusan adalah hasil pemecahan masalah yang dihadapi dengan tegas. Suatu keputusan merupakan jawaban yang pasti terhadap suatu pertanyaan.

Menurut Mary Follet

Keputusan adalah suatu atau sebagai hukum situasi. Apabila semua fakta dari suatu dari situasi itu dapat diperolehnya dan semua terlibat, baik pengawas maupun pelaksana mau mentaati ketentuannya maka tidak sama dengan mentaati perintah.

Menurut James A.F. Stoner

Keputusan adalah pemilihan di antara alternatif. Definisi ini mengandung tiga pengertian yaitu : ada pilihan atas dasar logika, ada beberapa alternatif yang harus dan dipilih satu yang terbaik dan ada tujuan yang ingin dicapai dan keputusan itu maka mendekatkan pada tujuan tersebut.

Menurut Prajudi Atmosudirjo

Keputusan adalah suatu pengakhiran daripada proses pemikiran tentang suatu masalah untuk menjawab pertanyaan apa yang harus diperbuat guna mengatasi masalah tersebut dengan menjatuhkan pilihan pada satu alternatif.

Dari pengertian keputusan di atas dapat disimpulkan bahwa keputusan adalah suatu pemecahan masalah sebagai suatu hukum situasi yang dilakukan melalui pemilihan satu alternatif dari beberapa alternatif.

\section{Pengertian Pengambilan Keputusan}

Adapun pengertian dari pengambilan keputusan yaitu dapat dijabarkan sebagai berikut (Hasan, 2002:10) :

a. Menurut George R. Terry

Pengambilan keputusan adalah pemilihan alternatif perilaku tertentu dari dua atau lebih alternatif yang ada.

b. Menurut S.P. Siagian

Pengambilan keputusan adalah suatu pendekatan yang sistematis terhadap hakikat alternatif yang dihadapi dan mengambil tindakan yang menurut perhitungan merupakan tindakan yang paling tepat. 
c. Menurut James A.F Stoner

Pengambil keputusan adalah proses yang digunakan untuk memilih suatu tindakan sebagai cara pemecahan masalah.

Dari pengertian pengambilan keputusan di atas dapat disimpulkan bahwa pengambilan keputusan adalah suatu proses pemilihan alternatif terbaik dari beberapa alternatif secara sistematis untuk ditindak lanjuti sebagai suatu cara pemecahan masalah.

\section{Sistem Pendukung Keputusan (SPK)}

Konsep Sistem Pendukung Keputusan ditandai dengan sistem interaktif berbasis komputer yang membantu pengambil keputusan memanfaatkan data dan model untuk menyelesaikan masalah yang tidak terstruktur. Pada dasarnya SPK dirancang untuk mendukung seluruh tahap pengambilan keputusan mulai dari mengidentifikasi masalah, memilih data yang relevan, menentukan pendekatan yang digunakan dalam proses pengambilan keputusan, sampai mengevaluasi pemilihan alternatif (Hasan, 2002:27).

\section{Pengertian Metode Fuzzy MADM}

Fuzzy Multiple Attribute Decision Making (FMADM) adalah suatu metode yang digunakan untuk mencari alternatif optimal dari sejumlah alternatif dengan kriteria tertentu. Inti dari FMADM adalah menentukan nilai bobot untuk setiap atribut, kemudian dilanjutkan dengan proses perankingan yang akan menyeleksi alternatif yang sudah diberikan. Pada dasarnya, ada 3 pendekatan untuk mencari nilai bobot atribut, yaitu pendekatan subyektif, pen-dekatan obyektif dan pendekatan integrasi antara subyektif \& obyektif. Masing-masing pendekatan memiliki kelebihan dan kelemahan. Pada pendekatan subyektif, nilai bobot ditentukan berdasarkan subyektifitas dari para pengambil keputusan, sehingga beberapa faktor dalam proses perankingan alternatif bisa ditentukan secara bebas. Sedangkan pada pendekatan obyektif, nilai bobot dihitung secara matematis sehingga meng-abaikan subyektifitas dari pengambil ke-putusan. (Kusumadewi, 2007).

\section{Algoritma Fuzzy MADM}

Algoritma Fuzzy MADM adalah :

Memberikan nilai setiap alternatif (Ai) pada setiap kriteria $(\mathrm{Cj})$ yang sudah ditentukan, dimana nilai tersebut di peroleh berdasarkan nilai crisp; $i=1,2, \ldots m$ dan $j=1,2, \ldots n$.
Memberikan nilai bobot (W) yang juga didapatkan berdasarkan nilai crisp.

Memberikan normalisasi matriks dengan cara menghitung nilai rating kinerja ternormalisasi (rij) dari alternatif Ai pada atribut $\mathrm{Cj}$ berdasarkan persamaan yang disesuaikan dengan jenis atribut (atribut keuntungan/benefit=MAKSIMUM atau atribut biaya/cost=MINIMUM). Apabila berupa artibut keuntungan maka nilai crisp (Xij) dari setiap kolom atribut dibagi dengan nilai crisp MAX (MAX Xij) dari tiap kolom, sedangkan untuk atribut biaya, nilai crisp MIN (MIN Xij) dari tiap kolom atribut dibagi dengan nilai crisp (Xij) setiap kolom.

Melakukan proses perankingan dengan cara mengalikan matriks ternormalisasi (R) dengan nilai bobot $(\mathrm{W})$.

Menentukan nilai preferensi untuk setiap alternatif (Vi) dengan cara menjumlahkan hasil kali antara matriks ternormalisasi (R) dengan nilai bobot (W). Nilai Vi yang lebih besar mengindikasikan bahwa alternatif $\mathrm{Ai}$ lebih terpilih.

\section{ANALISA DAN DESAIN SISTEM}

Dalam perancangan website ini penulis mempergunakan Macromedia Dreamweaver MX 2004 sebagai pembuatan website, sedangkan perancangan database menggunakan MySQL sebagai penyimpanan, dan Apache digunakan sebagai web server.

\section{Data Flow Diagram}

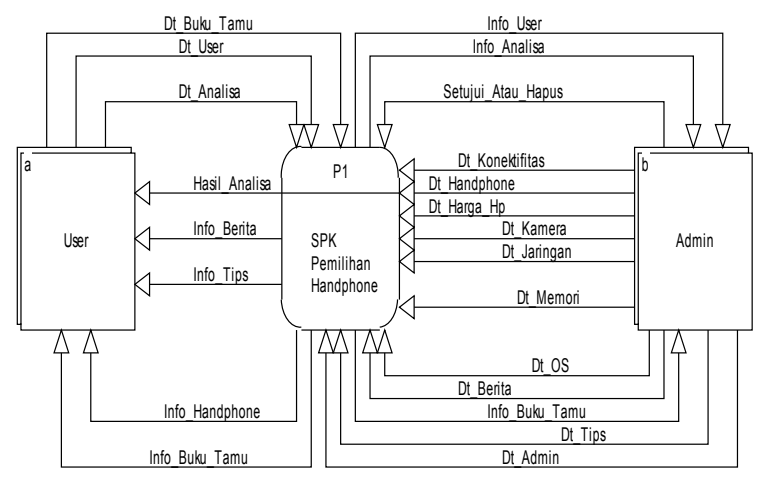

Gambar 1 Context Diagram

Keterangan :

Context Diagram dari alur Sistem Pendukung Keputusan Pemilihan Handphone Dengan Metode FMADM. Di sistem ini terdapat entitas user dan admin yang berhubungan langsung dengan Sistem Pendukung Keputusan Pemilihan Handphone Dengan Metode FMADM. Pada user, data yang diinputkan berupa data user dan 
data analisa. Sedangkan dari sistem, user mendapatkan hasil analisa dan info handphone. Pada entitas admin, sistem memberikan info user ke admin.

\section{IMPLEMENTASI SISTEM}

Implementasi

Menu utama Sistem Pendukung Keputusan Untuk Pemilihan Handphone Dengan Metode Fuzzy Multiple Attribute Decision Making yang ada di halaman utama (index) adalah sebagai berikut :

\section{Halaman Utama (Index)}

Halaman Beranda

Halaman Beranda, merupakan halaman yang pertama kali muncul pada saat masuk ke website Sistem Pendukung Keputusan Untuk Pemilihan Handphone Dengan Metode FMADM.

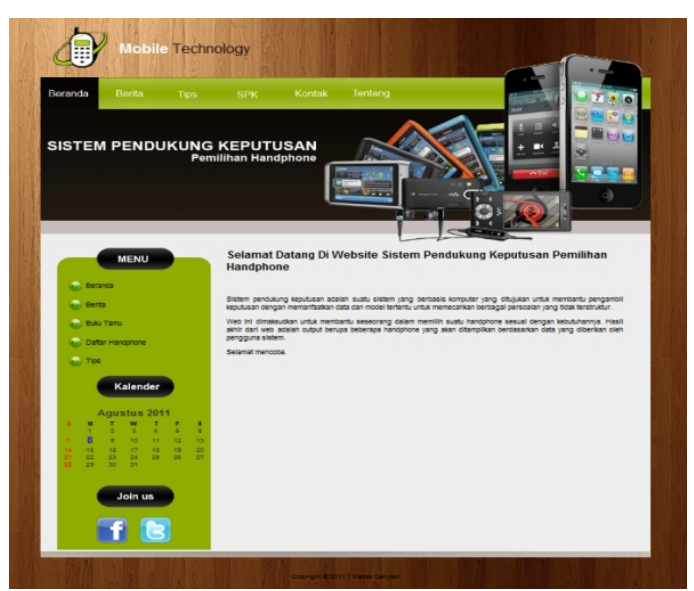

Gambar 2 Halaman Beranda

Pada halaman ini berisikan tombol Beranda, Berita, Tips, SPK, Kontak, Tentang, serta Daftar Handphone yang akan link ke halaman untuk menampilkan daftar handphone yang tersedia.

\section{Halaman Berita}

Pada halaman ini terdapat berita-berita terkini seputar teknologi dunia handphone dan akan terupdate secara berkala.

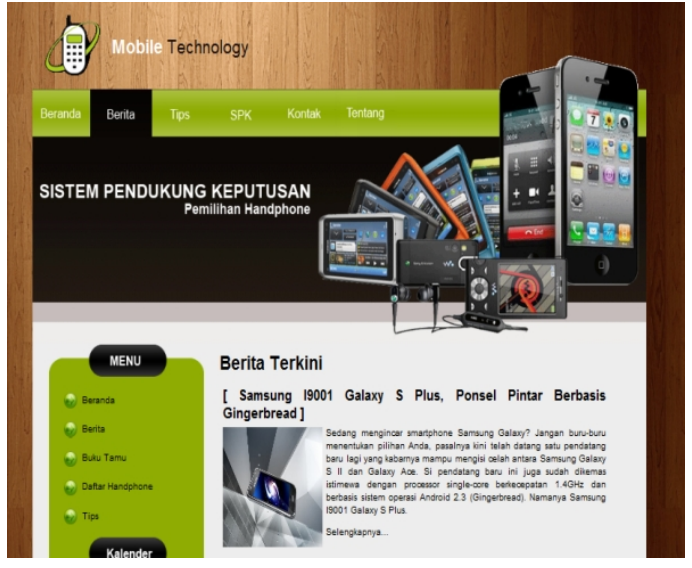

Gambar 3 Halaman Berita

\section{Halaman Tips}

Pada halaman ini terdapat tips-tips terkini seputar teknologi dunia handphone dan akan terupdate secara berkala.

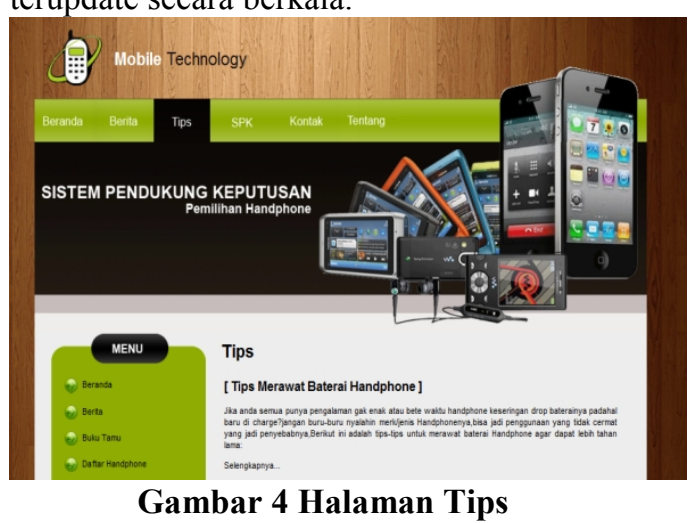

\section{Halaman SPK}

Halaman SPK ini untuk membantu user dalam melakukan pemilihan handphone yang sesuai dengan kebutuhannya, namun sebelum bisa menggunakannya user terlebih dahulu harus mengisi beberapa data mengenai data user pada halaman user.

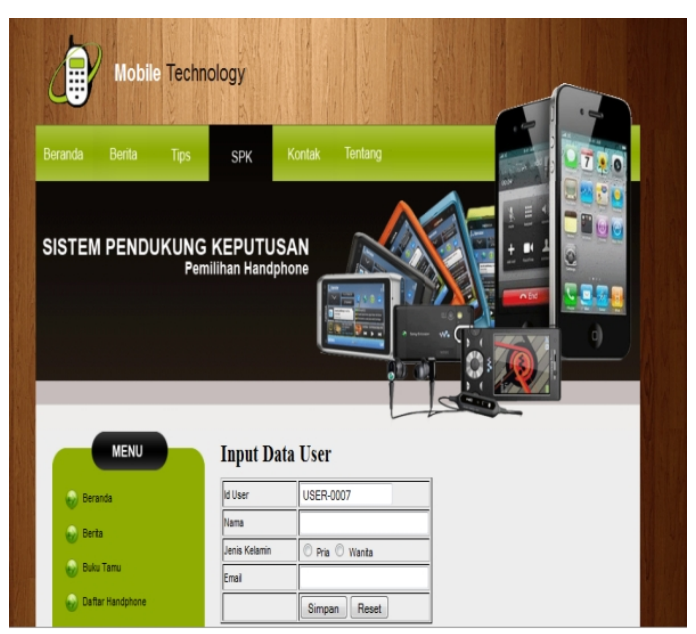

Gambar 5 Halaman User 
Halaman SPK menampilkan beberapa pertanyaan yang akan dijawab oleh user sesuai dengan kebutuhan handphone yang diinginkan.

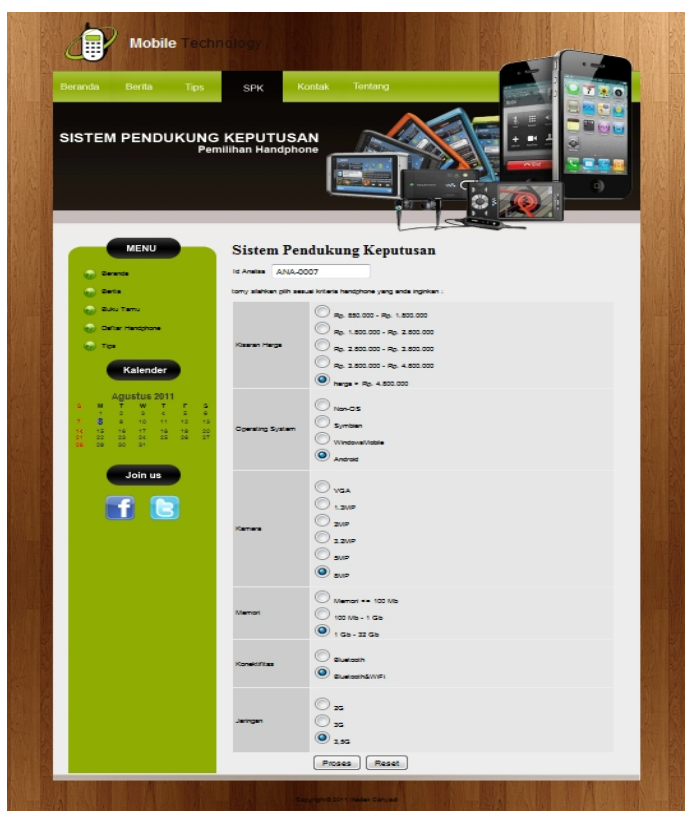

Gambar 6 Halaman SPK

Halaman hasil SPK menampilkan hasil dari proses dan pencocokan sehingga menghasilkan keputusan beberapa handphone yang sesuai dengan pilihan kebutuhan yang diinginkan oleh user.

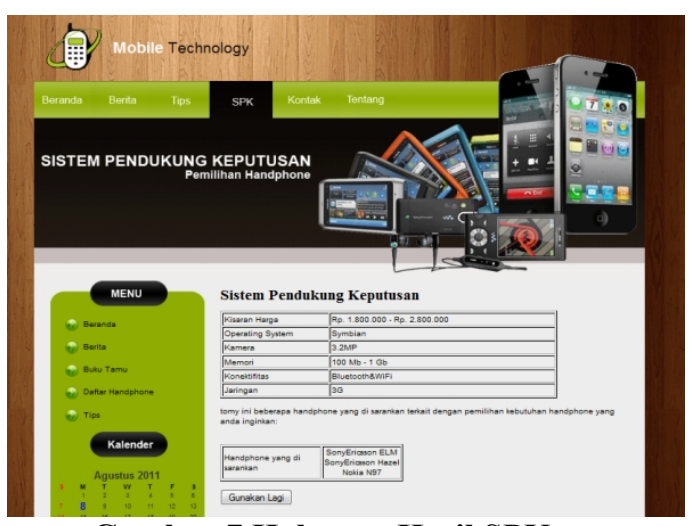

Gambar 7 Halaman Hasil SPK

Halaman info detail hasil menampilkan info detail dari hasil handphone yang diperoleh oleh user.

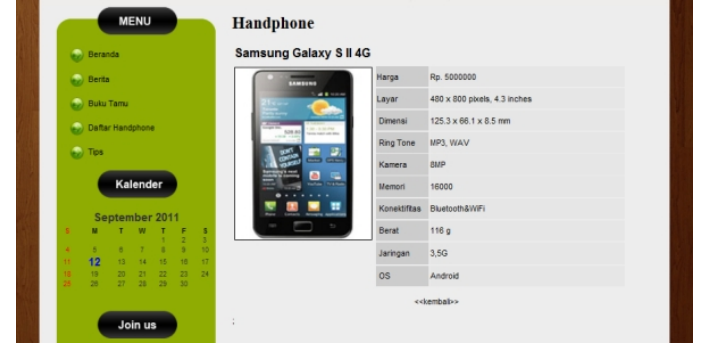

Gambar 8 Halaman Info Detail Hasil

\section{Halaman Kontak}

Pada halaman ini terdapat alamat email admin jika seorang pengunjung (user) ingin menanyakan sesuatu secara privasi kepada admin agar tidak dapat diketahui oleh orang lain.

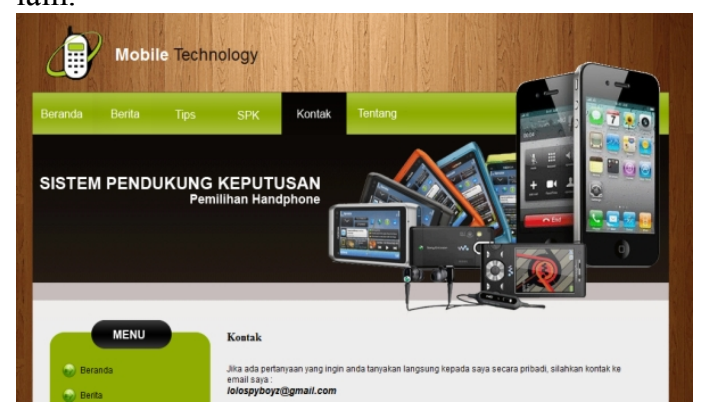

Gambar 9 Halaman Kontak

\section{Halaman Tentang}

Pada halaman ini hanya menjelaskan tentang dibuatnya web sistem pendukung keputusan pemilihan handphone.

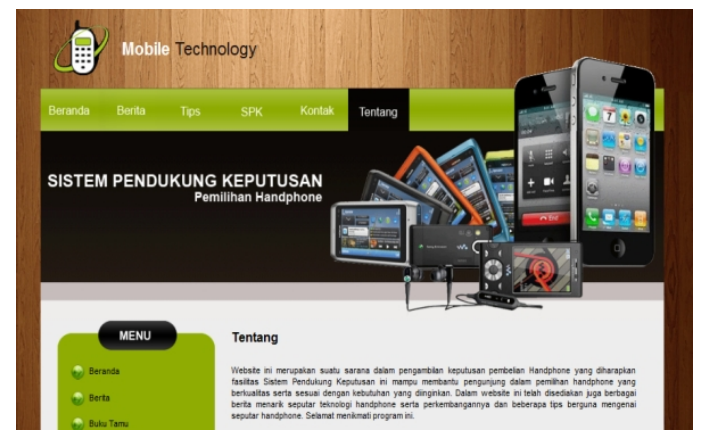

Gambar 10 Halaman Tentang

\section{Halaman Buku Tamu}

Pada halaman buku tamu ini memperlihatkan mengenai pesan yang ingin ditinggalkan user untuk admin agar bisa mengembangkan web tersebut lebih lanjut. Pesan yang ditinggalkan oleh user terlebih dahulu akan disetujui oleh admin untuk bisa di tampilkan pada halaman buku tamu untuk menghindari kata-kata yang kurang sopan. 


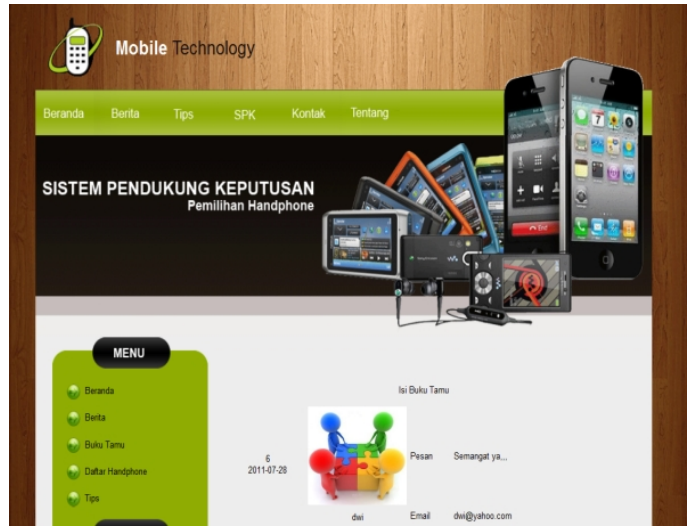

Gambar 11 Halaman Buku Tamu

\section{Halaman Isi Buku Tamu}

Halaman ini untuk meninggalkan pesan atau saran yang mungkin bisa admin gunakan sebagai acuan untuk mengembangkan sistem pendukung keputusan ini agar sesuai dengan kebutuhan yang diinginkan oleh user.

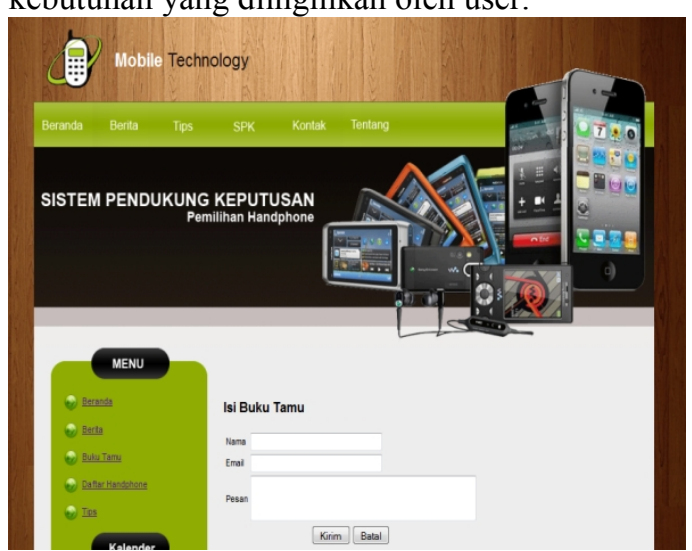

Gambar 12 Halaman Isi Buku Tamu

\section{Halaman Daftar Handphone}

Halaman Daftar Handphone merupakan halaman yang nenyajikan informasi - informasi produk handphone yang ada.

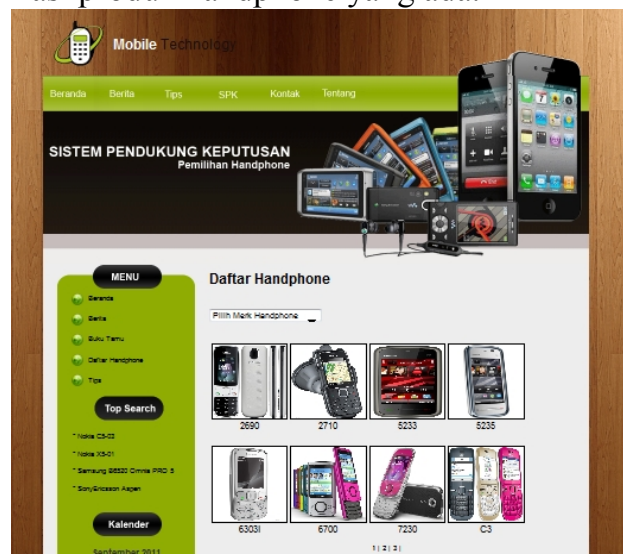

Gambar 13 Halaman Daftar Handphone
Pada halaman ini pengunjung website hanya dapat melihat produk handphone yang ada tanpa melakukan pemilihan handphone. Pemilihan handphone hanya dapat dilakukan di halaman SPK setelah user mengisi beberapa data mengenai data diri user, untuk memulai melakukan proses pemilihan handphone sesuai dengan kebutuhan handphone yang diingkan oleh user.

\section{Halaman Utama (Admin)}

Menu utama Admin Sistem Pendukung Keputusan Untuk Pemilihan Handphone Dengan Metode FMADM yang ada di halaman utama (admin) adalah sebagai berikut :

\section{Halaman Login Administrator}

Untuk dapat masuk ke halaman Admin diharuskan login terlebih dahulu, jika username atau password yang dimasukkan tidak sesuai dengan data yang tersimpan maka akan tampil pesan error, dan bila username dan password benar maka akan masuk ke halaman utama administrator.

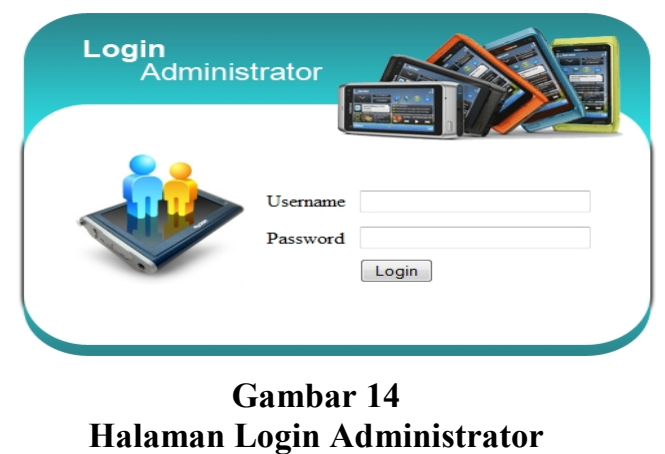

\section{Halaman Utama Administaror}

Halaman utama administrator merupakan halaman beranda yang tampil apabila admin sudah melakukan login.

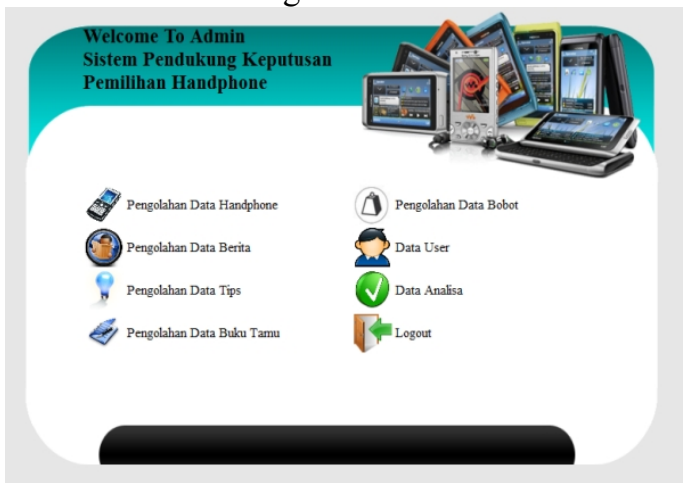

Gambar 15 Halaman Beranda Administrator 
Halaman Pengolahan Data Handphone Halaman pengolahan data handphone merupakan halaman yang berisikan data handphone yang bisa ditambah, diedit, maupun dihapus yang dilakukan oleh admin yang nantinya data handphone itu akan muncul pada menu daftar handphone.

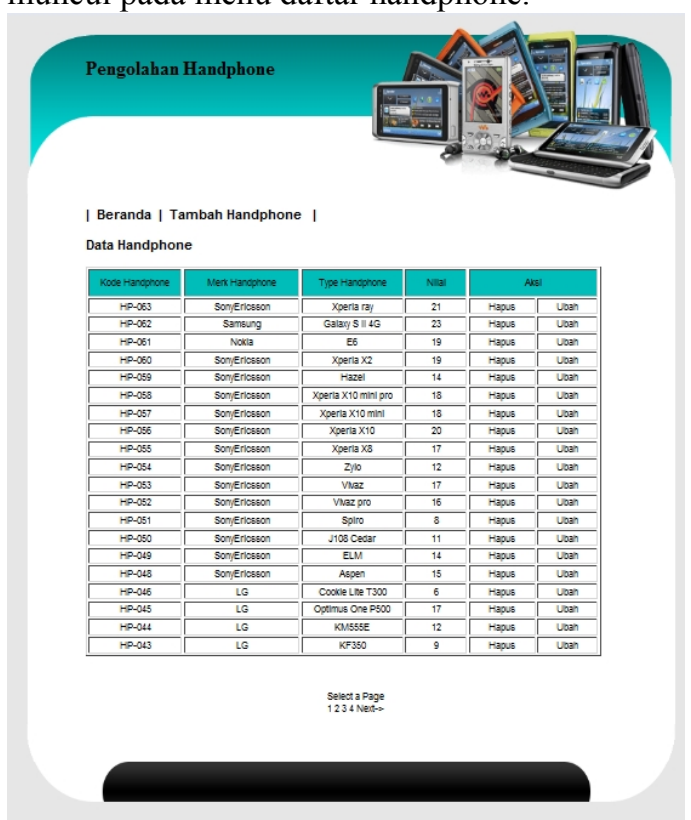

Gambar 16 Halaman Pengolahan Data Handphone

\section{Halaman Pengolahan Data Berita}

Halaman pengolahan data berita merupakan halaman untuk mengedit, menghapus, maupun menambahkan suatu berita yang dilakukan oleh admin yang nantinya akan muncul pada menu berita user.

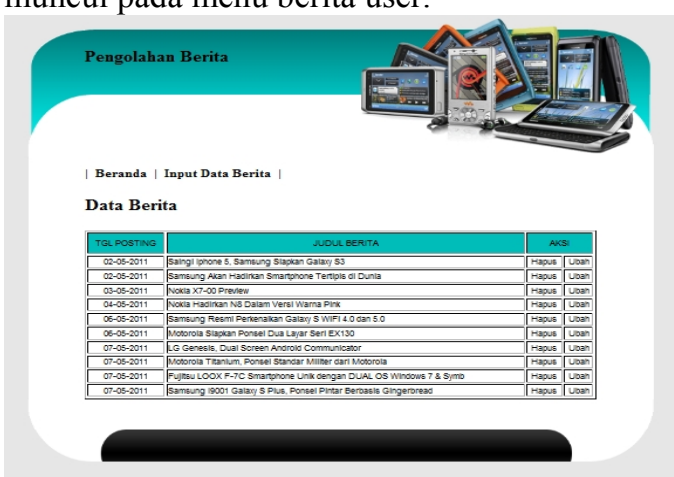

\section{Gambar 17 Halaman Pengolahan Data} Berita

\section{Halaman Pengolahan Data Tips}

Halaman pengolahan data tips merupakan halaman untuk mengedit, menghapus, maupun menambahkan suatu tips yang dilakukan oleh admin yang nantinya akan muncul pada menu tips user.

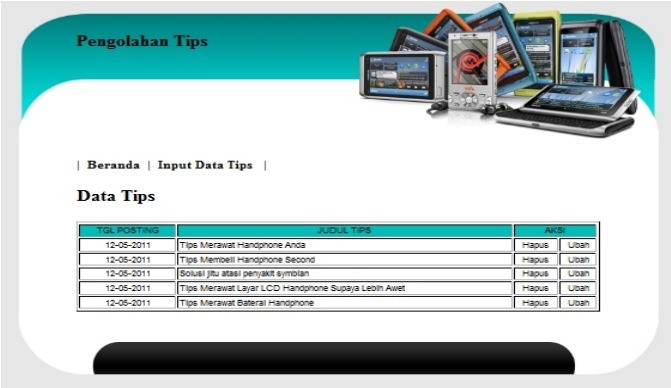

Gambar 4.18 Halaman Pengolahan Data Tips

Halaman Pengolahan Data Buku Tamu Pada halaman pengolahan data buku tamu merupakan halaman untuk mensetujui atau menghapus pesan yang ditinggalkan oleh user saat melakukan pengisian pada halaman buku tamu.

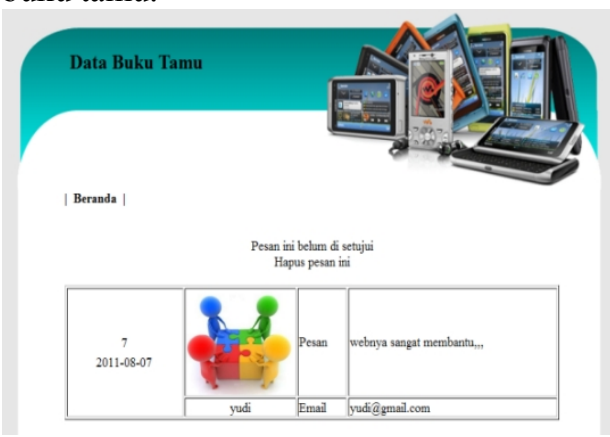

\section{Gambar 19 Halaman Pengolahan Data Buku Tamu}

\section{Halaman Pengolahan Data Bobot}

Halaman pengolahan data bobot merupakan halaman untuk mengelola bobot dari masingmasing kriteria handphone.

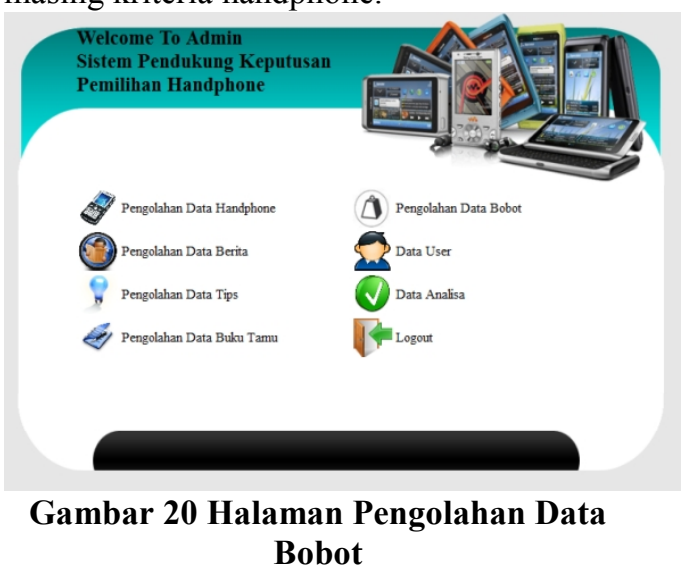

Halaman Pengolahan Data Bobot Harga HandphonePada halaman ini terdapat data bobot harga kamera yang dapat diedit, dihapus, maupun ditambah data bobot harga kamera yang baru. 


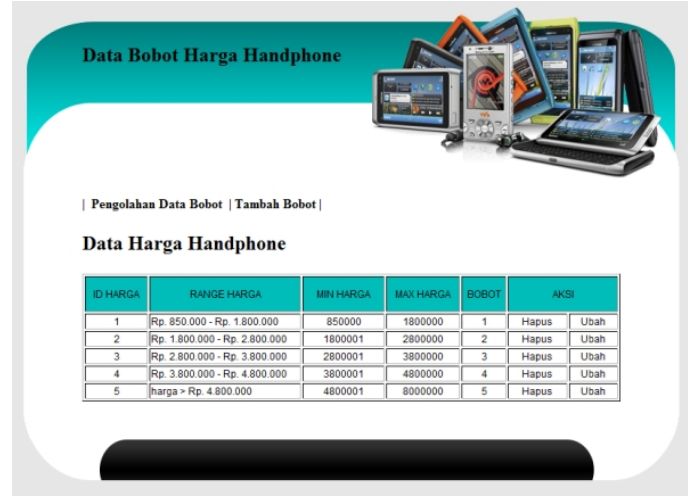

Gambar 21 Halaman Pengolahan Data Bobot Harga Handphone

Halaman Pengolahan Data Bobot Operating System

Pada halaman ini terdapat data bobot operating system yang dapat diedit, dihapus, maupun ditambah data bobot operating system yang baru.

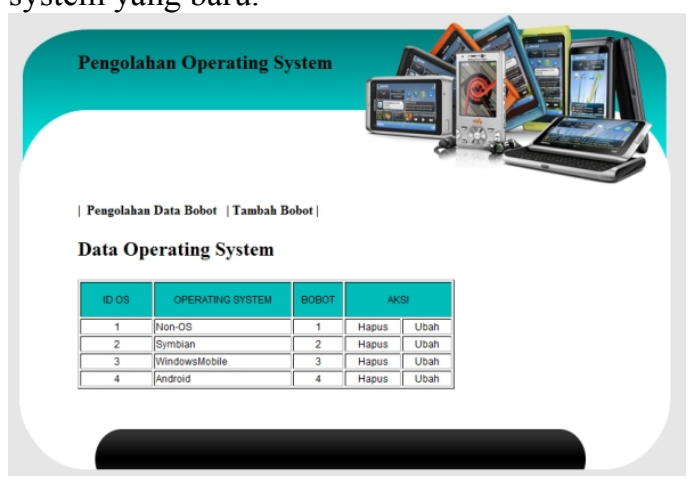

Gambar 22 Halaman Pengolahan Data Bobot Operating System

Halaman Pengolahan Data Bobot Kamera Pada halaman ini terdapat data bobot kamera yang dapat diedit, dihapus, maupun ditambah data bobot kamera yang baru.

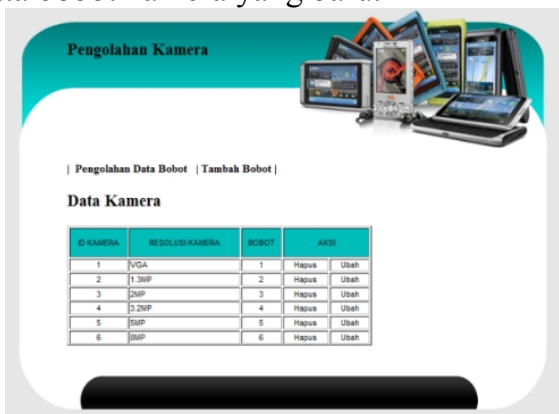

\section{Gambar 23 Halaman Pengolahan Data} Bobot Kamera

Halaman Pengolahan Data Bobot Konektifitas

Pada halaman ini terdapat data bobot konektifitas yang dapat diedit, dihapus, maupun ditambah data bobot konektifitas yang baru.

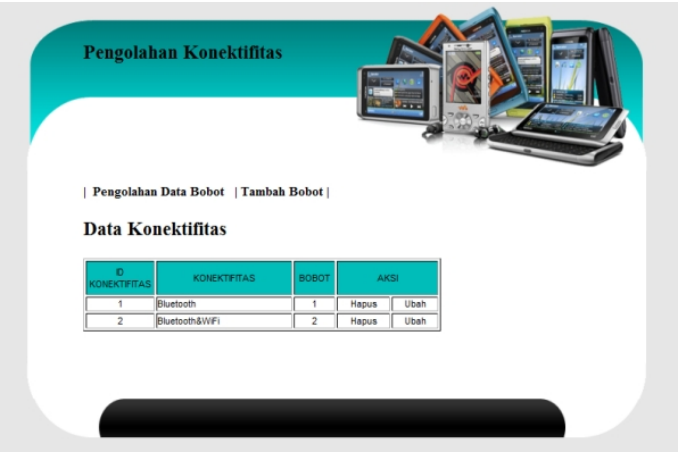

Gambar 24 Halaman Pengolahan Data Bobot Konektifitas

Halaman Pengolahan Data Bobot Memori Pada halaman ini terdapat data bobot memori yang dapat diedit, dihapus, maupun ditambah data bobot memori yang baru.

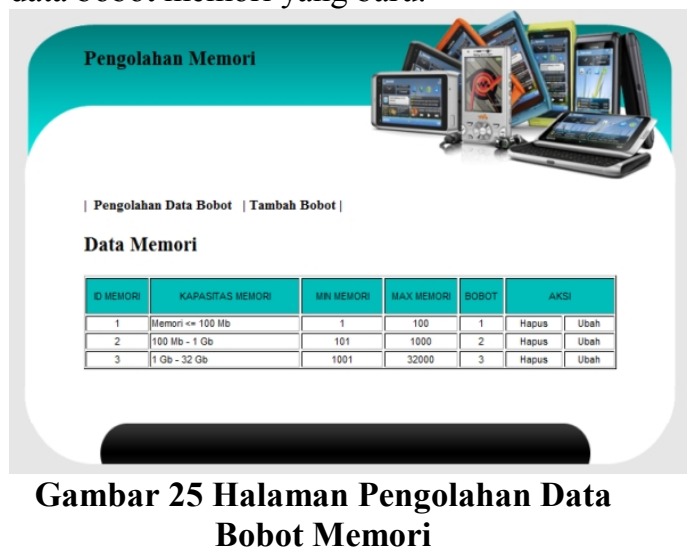

Halaman Pengolahan Data Bobot
Jaringan

Pada halaman ini terdapat data bobot jaringan yang dapat diedit, dihapus, maupun ditambah data bobot jaringan yang baru.

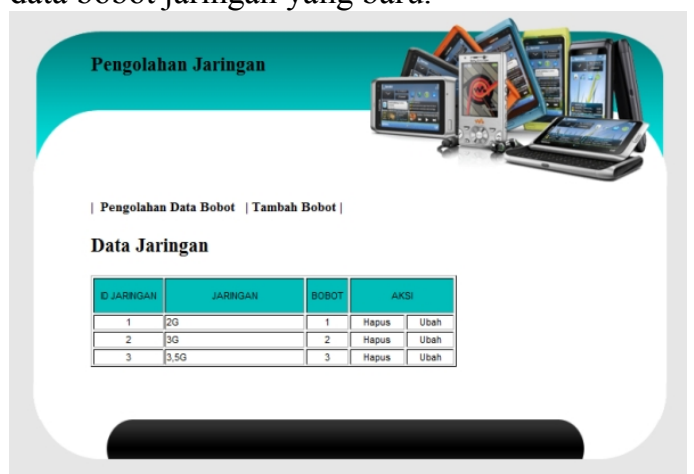

\section{Gambar 26 Halaman Pengolahan Data Bobot Jaringan}

\section{Halaman Data User}

Halaman ini berisi informasi dari user yang mengisi data form user untuk melakukan sistem pendukung keputusan pemilihan handphone. 


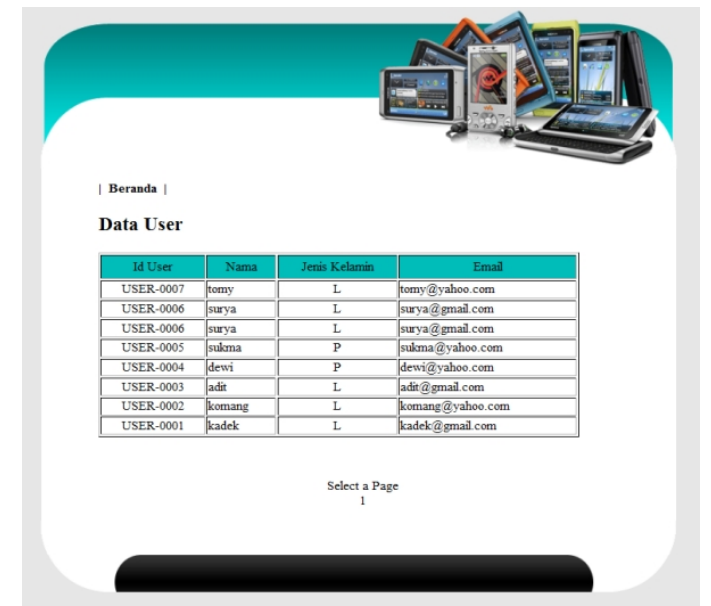

Gambar 27 Halaman Data User

\section{Halaman Data Analisa}

Halaman ini berisi informasi dari hasil analisa sistem pendukung keputusan pemilihan handphone yang dilakukan oleh user.

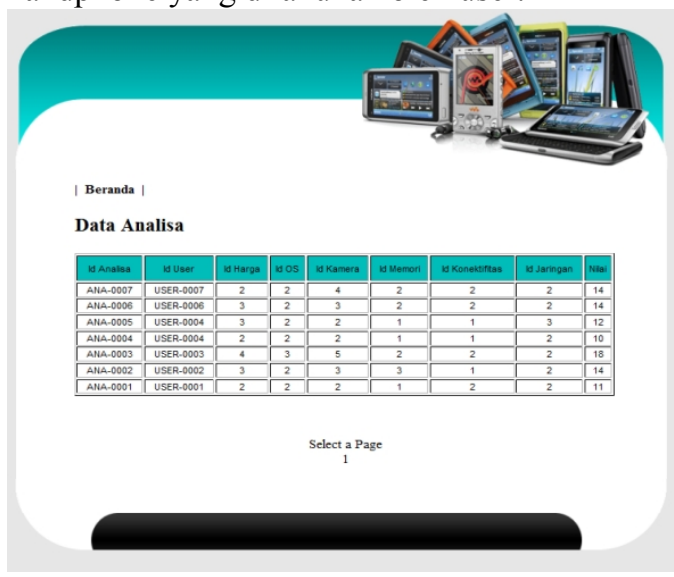

Gambar 28 Halaman Data Analisa

\section{SIMPULAN}

Kesimpulan yang diambil dengan mengacu pada pokok permasalahan serta beberapa saran guna pengembangan lebih lanjut. Berdasarkan penulisan laporan Skripsi serta hasil pengujian, maka dapat disimpulkan beberapa hal sebagai berikut :

1. Web ini merupakan suatu sarana dalam pengambilan keputusan pembelian handphone, dimana sistem pendukung keputusan ini mampu membantu seseorang dalam pemilihan handphone yang sesuai dengan kebutuhannya.

2. Sistem Pendukung Keputusan ini dapat memudahkan para peminat handphone untuk mengetahui handphone yang sesuai dengan ke butuhan yang diingin-kan.

3. Sistem berbasis web ini, mempermudah para user dalam memperoleh informasi dan mengakses data secara online.
4. Penggunaan metode FMADM dalam sistem pendukung keputusan dapat memberikan solusi dalam pemilihan handphone bagi user.

\section{DAFTAR PUSTAKA}

[1] Bunafit Nogroho, Membuat Aplikasi Penjualan dengan PHP \& MySQL, Ardana Melia, Yogyakarta, 2006

[2] Hartono J, Analisa \& Desain Sistem Informasi : Pendekatan Terstruktur Teori dan Praktek Aplikasi Bisnis, Andi, Yogyakarta, 1999

[3] Hasan I, Pokok-Pokok Materi Teori Pengambilan Keputusan, Ghalia Indonesia, Jakarta, 2002

[4] Janko, W.H. and Koch, S. (2005) "Sourcing Decisions in the Finance Sector: Economies of Scale and Knowledge Management", Proceedings of the International Finance Symposium, pp. 1-14, Istanbul, Turkey

[5] Jogiyanto, Analisis dan Desain Sistem Informasi, Andi offset ,Yogyakarta. 1989

[6] Kadarsah, Suryadi. Sistem Pendukung Keputusan, PT Remaja Rosdakarya, Bandung

[7] Kusumadewi, Sri. (2007). Diktat Kuliah Kecerdasan Buatan, Jurusan Teknik Informatika, Fakultas Teknologi Industri, Universitas Islam Indonesia.

[8] Kusumadewi, Sri., Hartati, S., Harjoko, A., dan Wardoyo, R. (2006). Fuzzy Multi-Attribute Decision Making (FUZZY MADM). Yogyakarta: Penerbit Graha Ilmu.

[9] Mulyanto Aunu R, Rekayasa Perangkat Lunak Jilid 1, Direktorat Pembinaan Sekolah Menengah Kejuruan, Jakarta, 2008

[10] Sutanta E, Sistem Basis Data, Graha Ilmu, Yogyakarta, 2004

[11] Syafii M, Membangun Aplikasi PHP dan MySQL, Andi, Yogyakarta, 2004 